\title{
Labour Mobility Within the Eu: Major Effects and Implications for the Main Sending and Receiving Economies
}

\author{
Noja Gratiela Georgiana, PhD, Lecturer \\ PhD Cand. Moroc Andrei
}

West University of Timisoara, Faculty of Economics and Business Administration, Romania

\begin{abstract}
The paper aims to analyse the effects induced by labour mobility within the European Union, focusing both on emigration and immigration effects for major sending and host economies in terms of the overall economic activity, empowering the business enterprise sector and labour market, as well as on economic (labour force) and non-economic (humanitarian, asylum seekers) migration. Labour mobility within the European Union is an important coordinate of the economic integration process and one of the freedoms granted to the member states, with significant consequences upon their economies. Nevertheless, the international labour migration mainly resides from wage differentials, working conditions or opportunities between sending and host economies, thus proving to be an important symbol of global economic inequality. Taking into consideration all these aspects, our analysis is based on developing various double-log fixed (LSDV) and random (ECM) effects models, using a panel structure that covers five main EU destination countries and ten New EU Member States, respectively a complex set of indicators compiled during 2000-2014 and 2006-2015. The models are processed through OLS and GLS methods of estimation, as well as by using the correlated panels corrected standard errors (PCSE) method, being completed by in-sample and out-of-sample predictions. The results show that immigration flows have important economic consequences leading to significant changes in labour market performances both for natives and foreign population (decreases in employment rates and lowering wage levels). Still, one of the most important positive effects of immigration reflected by the results obtained is represented by an increase in the number of innovative enterprises in the host country, thus confirming the theories linking migration to innovation. In terms of labour emigration, there is evidence to attest that it generates positive effects on the main sending economies from Central and Eastern Europe on the GDP per capita, earnings and exports, especially through remittances, but the overall negative impact is predominant.
\end{abstract}

Keywords: international migration, economic integration, innovation, employment, economic growth

JEL Classification: F22, F63

\section{Introduction}

Europe is facing nowadays one of the major challenges induces by international migration, a major frontier of globalization. Labour mobility within the EU is an important coordinate of the economic integration process and one of the four freedoms granted to the member states, with significant consequences (both positive and negative) upon their economies. Thus, the EU tends to be divided into two main areas in terms of migration (economic and humanitarian), respectively the New Member States (EU-13, since 2004, 2007 and 2013), as migrant sending countries, and the Old Member States (EU-15), most of them being migrant receiving countries or host economies (especially Germany in absolute terms, Austria and Sweden relative to their population, along with Italy and Spain even though with a slight decrease compared to previous years, but still among the top destinations especially for the emigrants coming from Central and Eastern Europe).

Thus, most countries from Central and Eastern Europe are labour exporting economies, Romania and Poland having a large stock of emigrants, respectively a major part of their labour force (especially highly skilled labour) is working outside their borders, thus inducing significant economic consequences. At the same time, Bulgaria, Slovak Republic and Lithuania have registered in 2015 large emigrant stocks. Still, on the other hand, if we analyse the entries of money sent by the 
emigrants back to their families in the source country, we can observe that Hungary, Czech Republic, Lithuania and Romania have also registered large levels of remittances.
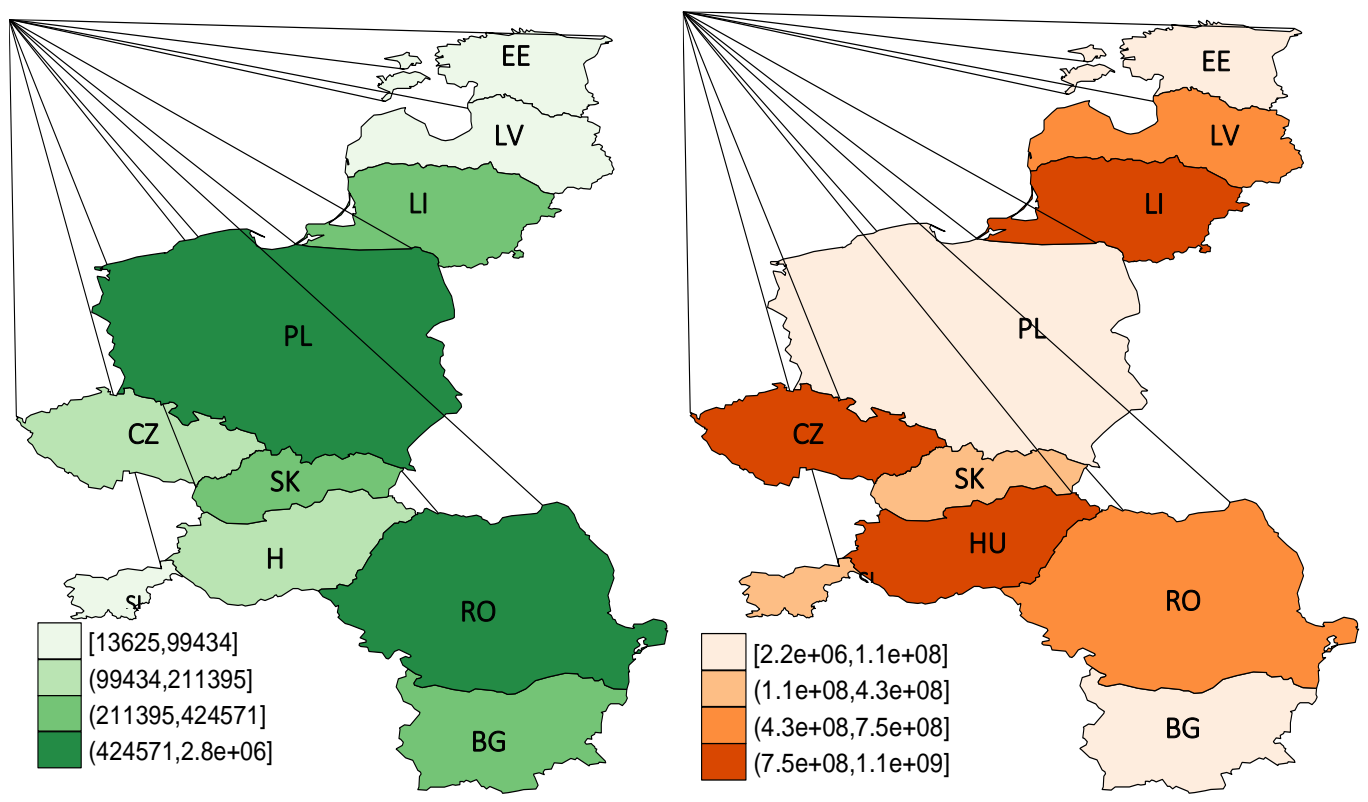

Figure 1: Stock of emigrants (left) and remittances (right) for the main

\section{sending countries from Central and Eastern Europe, 2015}

Source: own process based on Brucker et al. (2009) and World Bank data through Stata 13

Thus, even though the stock of emigrants is extremely high in the case of Poland or Bulgaria, remittances are at a much lower level compared to other neighbouring migrant sending countries.

Therefore, not all of the migrant origin countries from Central and Eastern Europe are necessarily characterized by an equivalent, proportional, level of remittances with respect to the number of registered emigrants. Still, Romania tends to differentiate itself from this point of view, in 2015 registering both high levels of emigrants and associated high remittances.

At the same time, Romania and Bulgaria are confronting with very low per capita incomes, labour market imbalances (high unemployment rates and low employment growth rates), along with a high at-risk-of-poverty rate, remittances thus representing an important source of external financing with positive effects upon their economies and especially for the families back home in terms of income, consumption, savings and investment. 

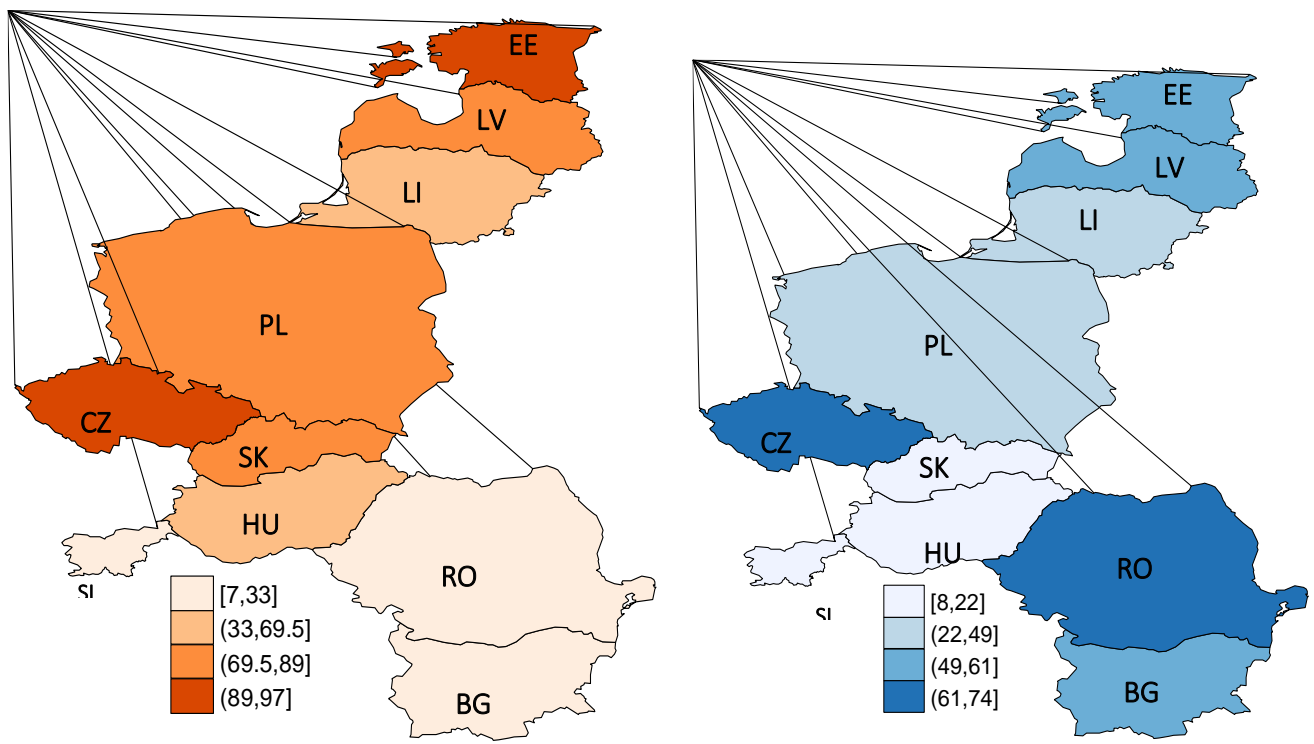

Figure 2: Per capita income (left) and at-risk-of-poverty rate (right) for the

\section{main sending countries from Central and Eastern Europe, 2015}

Source: own process based on World Bank data through Stata 13

Moreover, according to Noja and Son (2016) the anxiety towards emigrants from Central and Eastern Europe in the context of the latest enlargements, mainly 2007 (Romania and Bulgaria) and 2013 (Croatia), but as well towards asylum seekers and refugees coming from Syria and other Arab countries, highlights the importance of international migration policies, along with accurate and efficient immigrants integration strategies defined by the main European destination countries (Germany,

Austria,

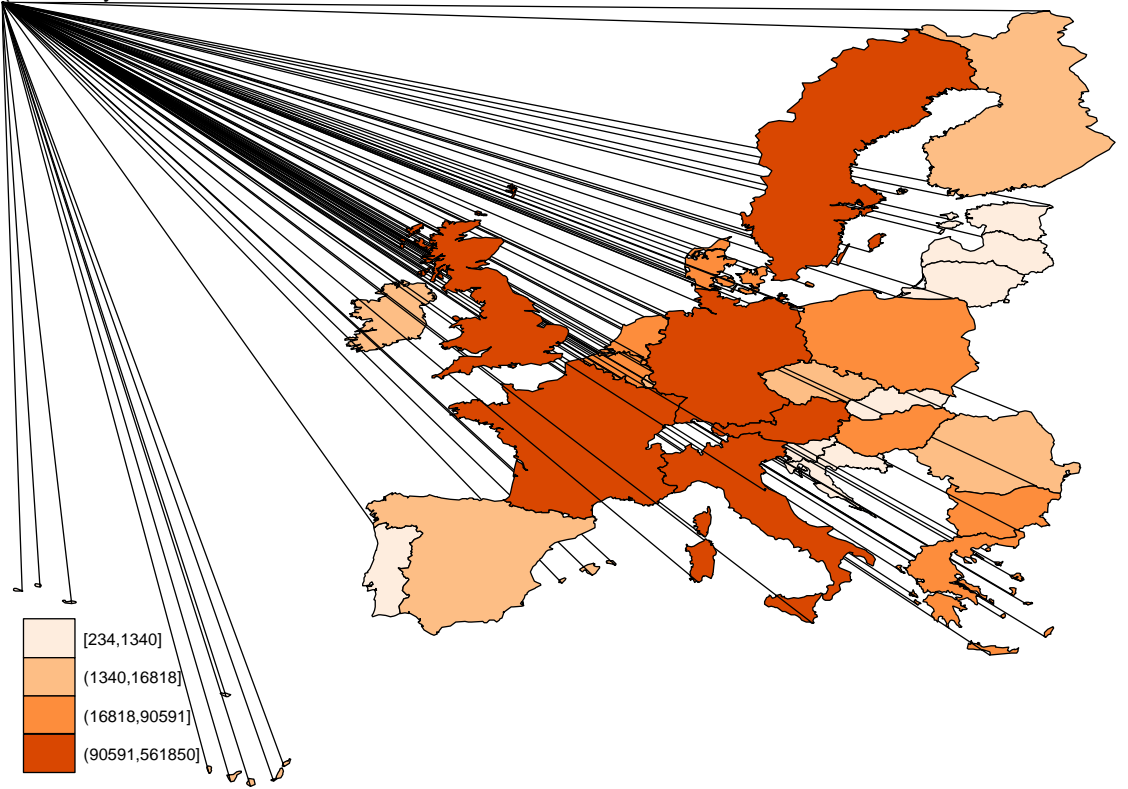

Sweden). 


\section{Figure 3: Total refugees and asylum seekers by country or territory}

\section{of asylum within the EU, mid-2015}

\section{Source: own process based on UNHCR data through Stata 13}

As in the case of previous refugee crises in the early 1990, the migration impact is cumulated in a few countries. Thus, across OECD, Turkey is the most affected, hosting at present approximately 1.9 million Syrians, mostly with a temporarily protective status, as well as a significant number of persons coming from Iraq. Moreover, other 300000 persons, mainly from Afghanistan, Iraq and Pakistan have an illegal residence in Turkey, waiting to transit towards the European Union to seek asylum. At the same time, more than 1.1 million Syrians find themselves in Lebanon, where the situation is increasingly uncertain, while a large number of refugees are in Jordan (about 630000) and Egypt (130000).

The large variety of migration corridors, migrant sending countries and migration motives shape this refugee crisis into one extremely difficult to approach and coordinate. Moreover, not only the fact that migrants came from various countries and territories of origin, but at the same time the main destination and asylum countries vary significantly across the EU. Thus, according to the OECD (2015) in Germany, during the first six months of 2015, Kosovo and Syria have each accounted $20 \%$ of the total asylum seekers, followed by Albania (15\%). In Sweden, Syrians have represented $27 \%$ of total migrants, followed by Eritreans and Afghanis with few over $10 \%$, while in Italy, Gambia was the first migrant sending country, followed by Senegal and Nigeria.

\section{Literature Review on International Migration and Labour Market Interdependencies}

The economic literature provides various theories and perspectives trying to explain international migration, both in terms of the migration decision and shaping factors of the migratory flows, and with respect to the economic consequences for migrant sending and receiving economies. Some of the most important approaches are the classical and neoclassical migration theories (mainly promoted by Lewis, 1954; Harris and Todaro, 1970; Massey et al., 1993). The classical migration approach explains the fact that migration and capital movements are performed with a certain intensity due to wage differentials between two capitalist economies, one characterised through labour surplus and the other by capital surplus. On the other hand, in the neoclassical perspective migration represents a complex phenomenon which induces unbalances, the migratory flows seizing when the equilibrium is reached (Harris and Todaro, 1970, p. 129).

Goss and Lindquist (1995) suggest that international labour migration generates a competition between migrants, which will thus lead to a decrease in wage levels for capital plentiful regions. At the same time, remittances towards the origin country can alleviate inequalities and wage differences that induce international labour mobility.

Moreover, the theory of migrant networks highlights the fact that international migration tends to increase as result of the interpersonal connections established between migrants that link origin and destination countries, due to relatively lower costs and associated risks. As a representative of this theory, Taylor (1986) reveals one of the most important incentives for international migration within host economies, respectively the presence of interpersonal migrant networks.

As considering the both sides on international migration and the main research questions regarding the emigration impact on sending countries and immigration effects on native workers and host economies, there are various theories trying to solve these questions.

Krause et al. (2016) considered the labour market integration of migrants, focusing on the Single European Labour Market, its performances, risks and opportunities, as well as the importance and usefulness of European labour mobility. Thus, they performed an online study among labour market exerts in Europe and concluded that most experts confirm the importance of a Single European Labour Market for improving the economic conditions, thus leading to welfare. Still, they seem to be uncertain about achieving these benefits. Moreover, in the case of EU labour mobility, the experts questioned by Krause et al. (2016) consider that the recognition of professional diplomas and qualifications, an optimization of the social security systems and over-passing the language barriers are some of the most important drivers to enhance labour mobility.

Bosetti et al. (2015) have analysed the interdependencies between highly skilled labour migration and innovation for a panel of 20 European economies during 1995-2008. Their empirical results suggest that a higher percentage of tertiary 
educated migrants integrated into the host economies labour markets and holding a job that requires higher qualifications and studies is also associated with a higher degree of knowledge creation. Thus, the brain drain-brain gain theory tends to be also confirmed by the Bosetti et al. (2015) which conclude that highly skilled migration leads to knowledge creation and innovation (measured through the number of patent applications), as well as to an increase in the general public scientific research (measured by the number of citations in published articles). Within this perspective, Bosetti et al. (2015) mention that the overall political efforts performed under the framework of Europe 2020 strategy will contribute to enhancing EU's competitiveness in innovation.

At the same time, Ozgen (2015) assessed the labour immigration effects on the firm innovation process within Western Europe, focusing on the main influential channels. The author mentions that in most of the European countries the migrants have significantly diversified in terms of origin country, gender or educational level, all of these aspects generating major economic consequences on the innovation performance of firms, as well as on intra-firm diversity.

Moreover, in terms of the general welfare impact of international migration in EU countries, Aubry et al. (2016) have quantified the effects induced by international migration upon the living standards of natives. The authors have developed a model which takes into account the interactions between the labour market, fiscal and market size effects (such as changes in the variety of goods available for consumers) induced by migration, along with trade relations between countries. Their results highlight that recent migration flows have generated positive effects on $69 \%$ of the native population in 34 OECD member states, respectively for $83 \%$ of the natives from the 22 richest OECD economies.

The emigration approach focuses more on migration effects on labour market outcomes, unemployment and economic growth generated through remittances and household impacts on those left behind.

The large economic literature on the impact of labour emigration on migrant sending economies highlights that it significantly depends on the way the capital-labour ratio is affected related to the persons remaining in the origin country. Moreover, the emigration effects are extremely different from one socio-economic group to another. Thus, overall, emigration tends to have a positive impact on those remaining, by increasing the economic welfare and reducing income inequalities in migrant sending countries (Clemens, 2011; de Haas, 2010; Taylor et al., 1996).

In Europe, Fertig and Kahanec (2015) have analysed the potential migration flows in the context of EU constant enlargement. Their results suggest that migration flows are largely shaped by policy variables and to a smaller extent by those economic and demographic. Thus, within the perspective of adopted and implemented migration policies, granting labour market free access to migrants by the hosting countries (Germany, Italy and Austria, in absolute terms and relative to their population) significantly increases the migration waves, especially on the short run.

\section{Methodology and Data: Developed Models, Ecuations, Limits and Testing}

\section{1 General form of developed models}

Our models follow the specific linear representation of the regression models with panel data, described by Baum (2001, p. 219) in order to proper analyse the emigration and immigration effects upon sending and receiving economies, configuration that was also used in previous researches (Son and Noja, 2012):

$$
\begin{aligned}
& y_{i t}=\sum_{k=1}^{k} x_{k i t} \beta_{k i t}+\varepsilon_{i t} \\
& i=1, \ldots, N \\
& t=1, \ldots, T
\end{aligned}
$$

where: $N$ is the number of panel units (countries), while $T$ represents the number of periods (time).

The fixed effects model or the Least Squares Dummy Variable (LSDV) model has the following representation (Baum, 2001, p. 220): 


$$
y_{i t}=x_{i t} \beta_{k}+z_{i} \delta+u_{i}+\varepsilon_{i t}
$$

where $x_{i t}$ is a $1 x k$ vector of variables varying between countries and in time, $\beta$ represents a $1 x k$ vector of $x$ coefficients, $z_{i}$ is a $1 \times p$ vector of the variables that are constant in time, but vary between countries (as elements of the panel), $\delta$ represents a $p \times 1$ vector of $z$ coefficients, $u_{i}$ is the individual effects, for every element of the panel, and $\varepsilon_{i t}$ is the disturbance term.

The random effects model or the Error Component Model (ECM) has the following representation (Baum, 2001, p. 227):

$$
y_{i t}=x_{i t} \beta+z_{i} \delta+\left(u_{i}+\varepsilon_{i t}\right)
$$

where: $u_{i}+\varepsilon_{i t}$ represents the compouned disturbance term, and $u_{i}$ reflects the individual effects.

The models developed in order to assess the immigration effects upon native workers and host country's labour market, including humanitarian migration, as well to evaluate the emigration impacts on sending economies, follow the specification of double-log simple and multiple regression models with panel data. These models were processed through OLS (Ordinary Least Squares) and GLS (Generalized Least Squares) methods of estimation in the case of fixed and random effects, respectively through the correlated panel corrected standard errors method (PCSE) method.

\section{2 Variables and indicators used for the empirical analysis}

In the analysis we focused on the international migration effects upon the general economic activity (economic growth, business enterprise sector, innovation) and labour market fundamentals (employment, employees with temporary contracts, earnings), respectively on the educational background (participation rate in education, upper-secondary and tertiary education) within the context of the globalization process and increased interdependencies between the economies globally.

We thus selected a large scale of indicators as proxy for the variables of developed models, ranging from the economic activity, labour market outcomes and education to various sides of the international migration process (immigration vs. emigration, labour vs. humanitarian migration), thus comprising:

i) international migration specific indicators: immigration flows and stocks, flows of refugees and asylum seekers, the stock of emigrants, remittances (mil. USD);

ii) economic activity and labour market indicators: total (mil. Euro) and per capita (Euro) GDP and the GDP per person employed (USD); employment and unemployment rates (\%) -total, foreign population; part-time employment rate and temporary contracts; earnings by two-earner married couple with two children (Euro) and earnings dispersion among employees (Decile 9/ Decile 5), average annual wages (USD); the educational attainment (both general and vocational) through secondary and tertiary education levels (the highest ISCED - International Standard Classification of Education level successfully completed) and the participation rate in education covering participation in formal and non-formal education and training; at-risk-of-poverty rate; business enterprise statistics - number of enterprises, number of innovative enterprises, total business expenditures on research and development.

iii) the globalization process: KOF Index of Economic Globalization and the value added by foreign controlled enterprises as a share of total value added (foreign affiliate statistics); international trade (exports and openness degree) and international investment (inflows and outflows of foreign direct investment).

The panel structure covers five main EU destination countries (Germany, Austria, Sweden, Italy and Spain) and ten New EU Member States from Central and Eastern Europe (Bulgaria, Romania, Hungary, Slovak Republic, Slovenia, Czech Republic, Poland, Lithuania, Latvia, Estonia). Within the performed analysis we covered the 2000-2014 period of time for the immigration analysis and the 2006-2015 period for the emigration analysis due to differences in data availability and used as main data sources the statistical database of the European Commission - Eurostat, the international migration 
database of OECD, World Bank - World Development Indicators and United Nations Database - UNHCR, ETH Swiss Federal Institute of Technology Zurich, UNU WIDER World Income Inequality Database.

\section{Results and Discussions}

The empirical analysis of labour mobility in Europe has a double objective: (i) first, to assess the emigration process for considered sending countries from Central and Eastern Europe through identifying the main modellers of emigrant stocks (migration incentives/ decisions), as well as in terms of the economic consequences induced by emigration (through the loss of a significant part of the origin country's labour force and remittances); (ii) second, to evaluate the immigration effects (both economic and humanitarian) within the main EU destination countries and upon their natives in terms of wages, labour market performance and integration of immigrants, business sector development and innovation, openness degree.

Therefore, in the first stage of our empirical research we developed a set of five macroeconometric models, processed through random-ECM (model 1) and fixed-LSDV (model 2) effects (the Hausman test validated the results of the random effects models with a chi2(6) $=1.43$ and Prob $>$ chi2 $=0.9641$ ), two-stage (model 3 ) and three-stage (model 4 ) least squares regressions and correlated panels corrected standard errors (PCSE - model 5).

\section{Table 1 Results of the models developed and processed for}

the analysis of emigration shaping factors

\begin{tabular}{|c|c|c|c|c|c|}
\hline & $\begin{array}{l}\text { (1) } \\
\text { log_Emigrants }\end{array}$ & $\begin{array}{l}\text { (2) } \\
\text { log_Emigrants }\end{array}$ & $\begin{array}{l}\text { (3) } \\
\text { log_Emigrants }\end{array}$ & $\begin{array}{l}\text { (4) } \\
\text { log_Emigrants }\end{array}$ & $\begin{array}{l}\text { (5) } \\
\text { log_Emigrants }\end{array}$ \\
\hline log_GDP_cap & $\begin{array}{l}0.0353 \\
(0.0202)\end{array}$ & $\begin{array}{l}0.0340 \\
(0.0204)\end{array}$ & $\begin{array}{l}-0.0345 \\
(0.112)\end{array}$ & $\begin{array}{l}-0.0345 \\
(0.108)\end{array}$ & $\begin{array}{l}-0.0345 \\
(0.0904)\end{array}$ \\
\hline log_Temp_contr & $\begin{array}{l}-0.0810 \\
(0.0469)\end{array}$ & $\begin{array}{l}-0.0738 \\
(0.0476)\end{array}$ & $\begin{array}{l}-0.651^{\text {t*t }} \\
(0.137)\end{array}$ & $\begin{array}{l}-0.651^{\text {t*t }} \\
(0.132)\end{array}$ & $\begin{array}{l}-0.651^{* * *} \\
(0.107)\end{array}$ \\
\hline log_Open_degre & $\begin{array}{l}0.714^{+* t *} \\
(0.0973)\end{array}$ & $\begin{array}{l}0.700^{* * *} \\
(0.101)\end{array}$ & $\begin{array}{l}0.980^{4+4} \\
(0.134)\end{array}$ & $\begin{array}{l}0.980^{\text {tw* }} \\
(0.130)\end{array}$ & $\begin{array}{l}0.980^{+3 * *} \\
(0.0633)\end{array}$ \\
\hline log_FDI_inward & $\begin{array}{l}0.343 \\
(0.189)\end{array}$ & $\begin{array}{l}0.373 \\
(0.194)\end{array}$ & $\begin{array}{l}0.317 \\
(0.302)\end{array}$ & $\begin{array}{l}0.317 \\
(0.291)\end{array}$ & $\begin{array}{l}0.317^{\star} \\
(0.138)\end{array}$ \\
\hline log_Earnings & $\begin{array}{l}0.0958^{*} \\
(0.0372)\end{array}$ & $\begin{array}{l}0.0979^{*} \\
(0.0376)\end{array}$ & $\begin{array}{l}0.145 \\
(0.134)\end{array}$ & $\begin{array}{l}0.145 \\
(0.129)\end{array}$ & $\begin{array}{l}0.145 \\
(0.123)\end{array}$ \\
\hline log_Poverty & $\begin{array}{l}-0.0778^{* *} \\
(0.0300)\end{array}$ & $\begin{array}{l}-0.0789^{*} \\
(0.0301)\end{array}$ & $\begin{array}{l}0.355^{* *} \\
(0.115)\end{array}$ & $\begin{array}{l}0.355^{*} \\
(0.111)\end{array}$ & $\begin{array}{l}0.355^{* * *} \\
(0.0984)\end{array}$ \\
\hline _cons & $\begin{array}{l}3.322+\cdots \\
(0.954) \\
\end{array}$ & $\begin{array}{l}3.327^{+* *+} \\
(0.880)\end{array}$ & $\begin{array}{l}1.142 \\
(1.702)\end{array}$ & $\begin{array}{l}1.142 \\
(1.642)\end{array}$ & $\begin{array}{l}1.142 \\
(0.801)\end{array}$ \\
\hline $\begin{array}{l}\mathrm{N} \\
\mathrm{R}^{2} \\
\end{array}$ & $\begin{array}{l}100 \\
0.3074\end{array}$ & $\begin{array}{l}100 \\
0.652\end{array}$ & $\begin{array}{l}100 \\
0.542\end{array}$ & $\begin{array}{l}100 \\
0.542\end{array}$ & $\begin{array}{l}100 \\
0.542\end{array}$ \\
\hline
\end{tabular}

Standard errors in parentheses

${ }^{*} p<0.05,{ }^{* *} p<0.01,{ }^{* * *} p<0.001$

Source: own process of panel data through Stata 13 econometric package

We selected several independent variables according to the relevant literature and constrained by low data availability which try to better capture the emigration incentives. Thus, the results obtained confirm the main migration decision theories, highlighting that the migrants primarily search for higher living standards abroad and better working conditions. Basically, according to our results an increase in poverty rates in the origin country induces higher emigrant stocks (a $3.55 \%$ increase confirmed by three of the five methods of estimation used). 
Moreover, the labour market fundamentals and flexibility measures used to increase employment reflected here through an increase in the number of persons employed on a temporary contracts basis represent a disincentive to migrate, thus reducing the size of the emigration stocks (by $0.651 \%$ also confirmed by three of the five methods of estimation used). Another important factor that can contribute to increased labour mobility in the present context of globalisation is the openness degree. Thus, higher openness degrees of migrant sending economies (in terms of exports and imports as percentage of the GDP) lead to an increase in the stock of emigrants for panel comprised economies.

Taking into consideration these aspects, we expanded our emigration analysis by considering its effects and thus developing a different set of eight simple regression models (one having as explanatory variable the stock of emigrants and the other remittances) processed through the correlated panels corrected standard errors (PCSE) method of estimation.

Table 2 Results of the models developed for the assessment of

emigration impacts on sending economies

\begin{tabular}{|c|c|c|c|c|}
\hline & $\begin{array}{l}\text { (1) } \\
\text { log_GDP_cap }\end{array}$ & $\begin{array}{l}(2) \\
\text { log_Export }\end{array}$ & $\begin{array}{l}\text { (3) } \\
\text { log_FDI_out }\end{array}$ & $\begin{array}{l}\text { (4) } \\
\text { log_Earnings }\end{array}$ \\
\hline log_Emigrants & $\begin{array}{l}0.195^{4 * *} \\
(0.0260)\end{array}$ & $\begin{array}{l}0.368^{+*+*} \\
(0.00671)\end{array}$ & $\begin{array}{l}-0.419^{+*+*} \\
(0.0279)\end{array}$ & $\begin{array}{l}0.0724 \\
(0.0421)\end{array}$ \\
\hline _cons & $\begin{array}{l}1.023^{* *} \\
(0.315)\end{array}$ & $\begin{array}{l}6.079^{+* *} \\
(0.110)\end{array}$ & $\begin{array}{l}6.870^{*+*} \\
(0.286)\end{array}$ & $\begin{array}{l}2.755^{*+*} \\
(0.516)\end{array}$ \\
\hline $\mathrm{N}$ & 100 & 100 & 100 & 100 \\
\hline$R^{2}$ & 0.073 & 0.336 & 0.317 & 0.012 \\
\hline & $\begin{array}{l}\text { (5) } \\
\text { log_Empl_rate }\end{array}$ & $\begin{array}{l}6) \\
\text { log_Temp_empl }\end{array}$ & $\begin{array}{l}\text { (7) } \\
\text { log_Poverty }\end{array}$ & $\begin{array}{l}\text { (8) } \\
\text { log_Edu_part }\end{array}$ \\
\hline log_Emigrants & $\begin{array}{l}-0.274^{+1+3} \\
(0.0608)\end{array}$ & $\begin{array}{l}-0.207^{+*+1} \\
(0.0290)\end{array}$ & $\begin{array}{l}0.119^{+4+t} \\
(0.0216)\end{array}$ & $\begin{array}{l}-0.00118 \\
(0.0707)\end{array}$ \\
\hline _cons & $\begin{array}{l}6.729^{+* *+} \\
(0.701)\end{array}$ & $\begin{array}{l}5.913^{\text {t+*t }} \\
(0.348)\end{array}$ & $\begin{array}{l}1.956^{+*+1} \\
(0.282)\end{array}$ & $\begin{array}{l}3.484^{\text {t+t+ }} \\
(0.919)\end{array}$ \\
\hline $\begin{array}{l}\mathrm{N} \\
\mathrm{R}^{2}\end{array}$ & $\begin{array}{l}100 \\
0.190\end{array}$ & $\begin{array}{l}100 \\
0.111\end{array}$ & $\begin{array}{l}100 \\
0.033\end{array}$ & $\begin{array}{l}100 \\
0.000\end{array}$ \\
\hline & $\begin{array}{l}1) \\
\text { log_GDP_cap }\end{array}$ & $\begin{array}{l}\text { (2) } \\
\text { log_Export }\end{array}$ & $\begin{array}{l}\text { (3) } \\
\text { log_FDI_out }\end{array}$ & $\begin{array}{l}(4) \\
\text { log_Earnings }\end{array}$ \\
\hline log_Remittances & $\begin{array}{l}0.290^{+* * *} \\
(0.0730)\end{array}$ & $\begin{array}{l}0.241^{\text {t+t+ }} \\
(0.0533)\end{array}$ & $\begin{array}{l}0.0326 \\
(0.0336)\end{array}$ & $\begin{array}{l}0.131^{\text {tot }} \\
(0.0340)\end{array}$ \\
\hline _cons & $\begin{array}{l}-2.310 \\
(1.418)\end{array}$ & $\begin{array}{l}5.815^{\text {t** }} \\
(1.050)\end{array}$ & $\begin{array}{l}1.146 \\
(0.656)\end{array}$ & $\begin{array}{l}1.056 \\
(0.694)\end{array}$ \\
\hline $\begin{array}{l}\mathrm{N} \\
\mathrm{R}^{2}\end{array}$ & $\begin{array}{l}100 \\
0.150\end{array}$ & $\begin{array}{l}100 \\
0.134\end{array}$ & $\begin{array}{l}100 \\
0.002\end{array}$ & $\begin{array}{l}100 \\
0.037\end{array}$ \\
\hline & $\begin{array}{l}\text { (5) } \\
\text { log_Empl_rate }\end{array}$ & $\begin{array}{l}\text { (6) } \\
\text { log_Temp_empl }\end{array}$ & $\begin{array}{l}\text { (7) } \\
\text { log_Poverty }\end{array}$ & $\begin{array}{l}\text { (8) } \\
\text { log_Edu_part }\end{array}$ \\
\hline log_Remittances & $\begin{array}{l}-0.0620 \\
(0.0550)\end{array}$ & $\begin{array}{l}-0.00270 \\
(0.0387)\end{array}$ & $\begin{array}{l}0.0254 \\
(0.0471)\end{array}$ & $\begin{array}{l}-0.168^{+4 *+2} \\
(0.0463)\end{array}$ \\
\hline _cons & $\begin{array}{l}4.628^{* *+} \\
(1.058)\end{array}$ & $\begin{array}{l}3.459^{+* *+} \\
(0.745)\end{array}$ & $\begin{array}{l}2.901^{* *} \\
(0.948)\end{array}$ & $\begin{array}{l}6.772^{+*+*} \\
(0.890)\end{array}$ \\
\hline $\mathrm{N}$ & 100 & 100 & 100 & 100 \\
\hline$R^{2}$ & 0.009 & 0.000 & 0.001 & 0.055 \\
\hline
\end{tabular}

Standard errors in parentheses

${ }^{*} p<0.05,{ }^{* *} p<0.01,{ }^{* * *} p<0.001$

Source: own process of panel data through Stata 13 econometric package 
The results highlight positive effects of emigration for migrant sending economies from Central and Eastern Europe only in terms of the overall economic activity (increases in the GDP per capita, level of household earnings through remittances, international trade operations).

There are significant negative effects on labour market outcomes (decreases in employment rates - both total and temporary employment), especially through the loss of a significant part of the labour force (mostly highly skilled labour), as well as on the educational background reflected by a reduction of the participation rate in education and training. Moreover, the results highlight that emigration tends to deepen the poverty levels by increasing the at-risk-of-poverty rates for considered economies.

From the immigration perspective, our main focus was on the major challenges faced by Europe nowadays, where large migrant flows have emerged in the context of European integration, and moreover recently due to increased waves of refugees and asylum seekers targeting Germany, Austria, Sweden or Turkey as main destination countries, through Eastern and Central Mediterranean or Western Balkans routes.

We thus developed two sets of twelve simple regression models processed through the correlated panels corrected standard errors method of estimation (in the first set we used as explanatory variable the stocks of immigrants and in the second set we used as independent variable the inflows of asylum seekers).

Table 3 Results of the models developed for the extended analysis of immigration economic consequences within main receiving countries

\begin{tabular}{|c|c|c|c|c|}
\hline & $\begin{array}{l}1) \\
\text { log_GDP_cap }\end{array}$ & $\begin{array}{l}\text { (2) } \\
\text { log_GDP_empl }\end{array}$ & $\begin{array}{l}\text { (3) } \\
\text { log_Unempl_rate }\end{array}$ & $\begin{array}{l}\text { (4) } \\
\text { log_Unempl_rate_forei } \\
\text { gn }\end{array}$ \\
\hline log_Imig_stock & $\begin{array}{l}-0.08622^{+* t} \\
(0.0164)\end{array}$ & $\begin{array}{l}-0.0662^{\text {t+t }} \\
(0.00464)\end{array}$ & $\begin{array}{l}0.108^{+*+*} \\
(0.0197)\end{array}$ & $\begin{array}{l}0.168^{\text {t+t+ }} \\
(0.0257)\end{array}$ \\
\hline _cons & $\begin{array}{l}10.88^{* *+*} \\
(0.133)\end{array}$ & $\begin{array}{l}11.20^{*+*} \\
(0.0419)\end{array}$ & $\begin{array}{l}1.1066^{*+*} \\
(0.154)\end{array}$ & $\begin{array}{l}1.357^{+*+*} \\
(0.195)\end{array}$ \\
\hline $\mathrm{N}$ & 70 & 75 & 75 & 75 \\
\hline$R^{2}$ & 0.172 & 0.533 & 0.182 & 0.142 \\
\hline & $\begin{array}{l}\text { (5) } \\
\text { log_Empl_rate }\end{array}$ & $\begin{array}{l}\text { (6) } \\
\text { log_Empl_foreign }\end{array}$ & $\begin{array}{l}\text { (7) } \\
\text { log_Wages }\end{array}$ & $\begin{array}{l}\text { (8) } \\
\text { log_Earn_disp }\end{array}$ \\
\hline log_Imig_stock & $\begin{array}{l}-0.04366^{+*+*} \\
(0.00675)\end{array}$ & $\begin{array}{l}-0.0249+*+1 \\
(0.00683)\end{array}$ & $\begin{array}{l}-0.0746^{\text {t*t+ }} \\
(0.00958)\end{array}$ & $\begin{array}{l}0.0288^{* * *} \\
(0.00367)\end{array}$ \\
\hline _cons & $\begin{array}{l}4.512^{* * *} \\
(0.0494)\end{array}$ & $\begin{array}{l}4.284^{*+*} \\
(0.0514)\end{array}$ & $\begin{array}{l}11.266^{* * *} \\
(0.0789)\end{array}$ & $\begin{array}{l}0.362^{+*+*} \\
(0.0263)\end{array}$ \\
\hline $\mathrm{N}$ & 75 & 75 & 75 & 75 \\
\hline $\mathrm{R}^{2}$ & 0.180 & 0.031 & 0.254 & 0.065 \\
\hline & $\begin{array}{l}\text { (9) } \\
\text { log_Edu_sec }\end{array}$ & $\begin{array}{l}\text { (10) } \\
\text { log_Edu_tert }\end{array}$ & $\begin{array}{l}(11) \\
\text { log_BERD }\end{array}$ & $\begin{array}{l}12) \\
\text { log_Innov_entrep }\end{array}$ \\
\hline log_Imig_stock & $\begin{array}{l}-0.0945^{5+*} \\
(0.0202)\end{array}$ & $\begin{array}{l}0.00970 \\
(0.0167)\end{array}$ & $\begin{array}{l}-0.330^{+*+*} \\
(0.0536)\end{array}$ & $\begin{array}{l}0.863^{*+*} \\
(1.82 \mathrm{e}-08)\end{array}$ \\
\hline _cons & $\begin{array}{l}4.475^{* *+*} \\
(0.152)\end{array}$ & $\begin{array}{l}2.901^{* * *} \\
(0.130)\end{array}$ & $\begin{array}{l}8.378^{* * *} \\
(0.437)\end{array}$ & $\begin{array}{l}3.398^{*+*} \\
(0.000000143)\end{array}$ \\
\hline $\mathrm{N}$ & 75 & 75 & 70 & 5 \\
\hline $\mathrm{R}^{2}$ & 0.073 & 0.001 & 0.166 & 0.777 \\
\hline
\end{tabular}

Standard errors in parentheses

${ }^{*} p<0.05,{ }^{* *} p<0.01,{ }^{* * *} p<0.001$

Source: own process of panel data through Stata 13 econometric package 
Our results suggest that there is evidence to confirm some of the major concerns regarding the negative impact of immigration on host economies. Thus, an increase in both stocks and inflows of immigrants within the five analysed countries leads to a reduction in GDP per capita and per person employed levels, reduces the labour market performances both for natives and other immigrants already established there (reflected to an increase in total and foreign unemployment rates and associated decreases in total and foreign employment rates), a decrease of wages and increased earnings dispersion. Still, one of the most important positive effects of immigration reflected by the results obtained is represented by an increase in the number of innovative enterprises in the host country, thus confirming the theories linking migration to innovation.

Table 4 Results of the models developed for the analysis of asylum seekers economic consequences within receiving countries

\begin{tabular}{|c|c|c|c|c|}
\hline & (1) & (2) & (3) & (4) \\
\hline & log_GDP_cap & log_GDP_empl & log_Unempl_rate & $\begin{array}{l}\text { log_Unempl_rate_forei } \\
\text { gn }\end{array}$ \\
\hline \multirow[t]{2}{*}{ log_asylum_infl } & $0.128^{*+* t}$ & $0.0251^{1+t+}$ & -0.0201 & -0.0646 \\
\hline & $(0.0209)$ & $(0.00696)$ & $(0.0238)$ & $(0.0805)$ \\
\hline \multirow[t]{2}{*}{ _cons } & $8.962^{*+*}$ & $10.45^{* *+}$ & $2.132^{+* *}$ & $3.280^{+*+*}$ \\
\hline & $(0.213)$ & $(0.0671)$ & $(0.242)$ & $(0.806)$ \\
\hline $\mathrm{N}$ & 70 & 75 & 75 & 75 \\
\hline \multirow[t]{3}{*}{$\mathrm{R}^{2}$} & 0.280 & 0.062 & 0.005 & 0.017 \\
\hline & (5) & (6) & (7) & (8) \\
\hline & log_Empl_rate & log_Empl_foreign & log_Wages & log_Earn_disp \\
\hline \multirow[t]{2}{*}{ log_asylum_infl } & $0.0604^{+*+*}$ & -0.0505 & $0.0996^{*+1+}$ & $-0.0780^{* * *}$ \\
\hline & $(0.00796)$ & $(0.0309)$ & $(0.0121)$ & $(0.00997)$ \\
\hline \multirow[t]{2}{*}{ _cons } & $3.581^{*+* t}$ & $4.594^{* * *}$ & $9.701^{*+*}$ & $1.353^{\text {t+*t }}$ \\
\hline & $(0.0809)$ & $(0.300)$ & $(0.120)$ & $(0.0961)$ \\
\hline $\mathrm{N}$ & 75 & 75 & 75 & 75 \\
\hline \multirow[t]{3}{*}{$\mathrm{R}^{2}$} & 0.281 & 0.104 & 0.371 & 0.389 \\
\hline & (9) & (10) & (11) & (12) \\
\hline & log_Edu_sec & log_Edu_tert & log_BERD & log_Innov_entrep \\
\hline \multirow[t]{2}{*}{ log_asylum_infl } & $0.292^{* *+*}$ & -0.0129 & $0.546^{+*+*}$ & 0.143 \\
\hline & $(0.0328)$ & $(0.0202)$ & $(0.0501)$ & (.) \\
\hline \multirow[t]{2}{*}{ _cons } & $0.867^{* *}$ & $3.103^{* * *+}$ & 0.461 & 8.777 \\
\hline & $(0.321)$ & $(0.205)$ & $(0.478)$ & (.) \\
\hline $\mathrm{N}$ & 75 & 75 & 70 & 5 \\
\hline $\mathrm{R}^{2}$ & 0.565 & 0.001 & 0.390 & 0.028 \\
\hline
\end{tabular}

Standard errors in parentheses

${ }^{*} p<0.05,{ }^{* *} p<0.01,{ }^{* * *} p<0.001$

Source: own process of panel data through Stata 13 econometric package

On the other hand, if we consider only the asylum seekers inflows into the main EU host economies analysed within the panel, the results tend to be contradictory and show positive effects of immigration (a possible explanation being the 
relatively small number of asylum seekers compared to labour immigrants during the analysed period, even though there are significant increases in the latest years).
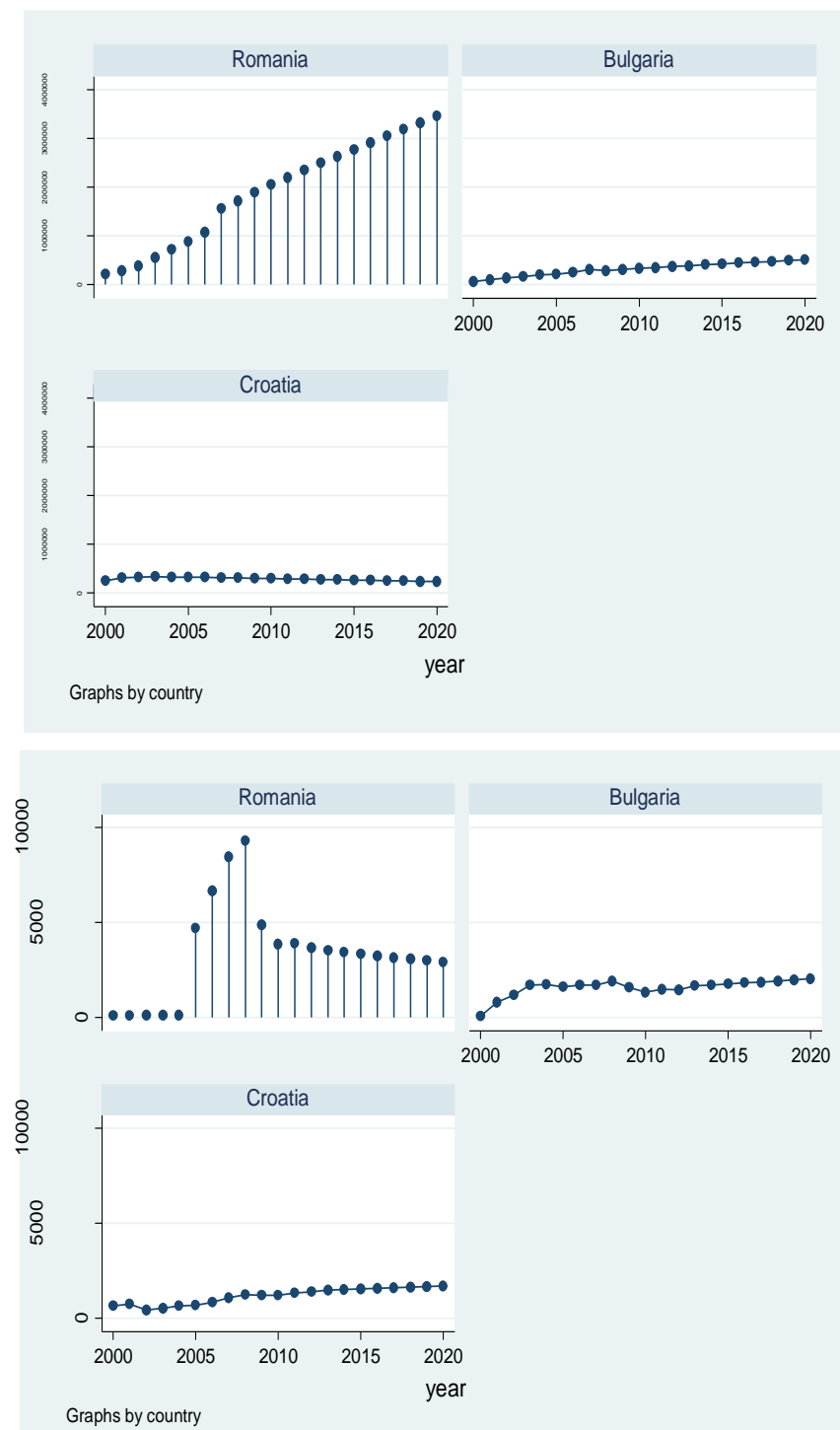

Figure 4: Estimated emigrants (stock) for the New EU Member States since

2007 (Romania and Bulgaria) and 2013 (Croatia), during 2000-2020

Source: own process based on panel data through Stata 13 
We completed the empirical analysis with in-sample and out-of-sample predictions until 2020 of the emigrants stock and remittances for three of the New EU Member States as sending economies considered in the panel - Romania, Bulgaria and Croatia and of the immigrants and asylum seekers inflows into one of the main destination country - Germany.
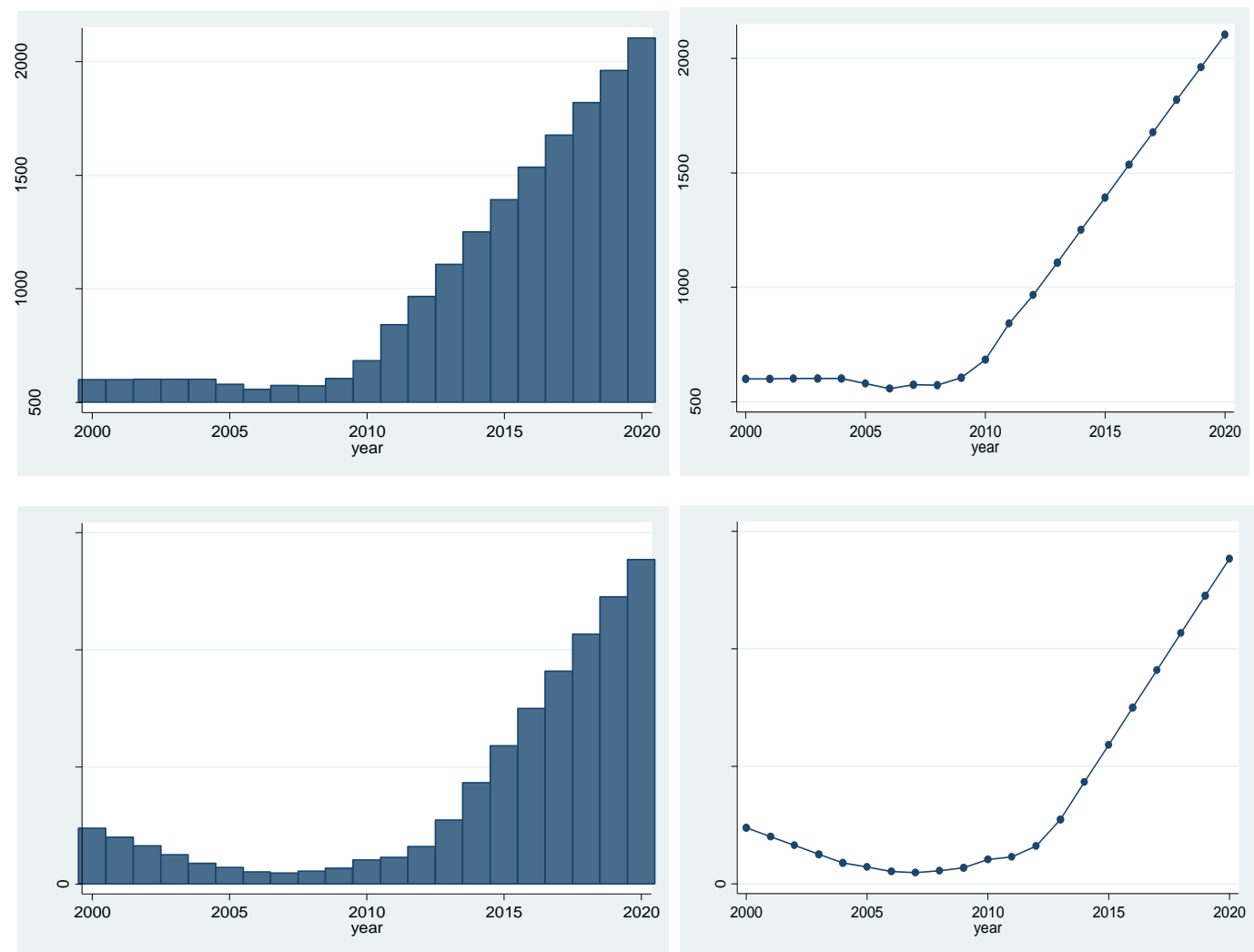

Figure 5: Estimated flows of immigrants and asylum seekers in the

\section{case of Germany during 2000-2020}

Source: own process based on panel data through Stata 13

We could thus observe that the stock of emigrants will continue to follow an increasing trend in the case of Romania, but the volume of remittances will decrease significantly, while Bulgaria and Croatia will register an approximately constant evolution, with a slight increase in remittances. At the same time, the inflows of immigrants and asylum seekers into Germany will continue to register an upward tendency, with major increases by the end of 2020 compared to previous years.

\section{Concluding Remarks}

Labour mobility in Europe is facing a major challenge nowadays in framework of the socio-economic and geopolitical context induced by the globalization process through increased interdependencies between economies globally.

Our empirical analysis was focused on developing various models which try to better capture the effects induced by increased migration flows (economic and humanitarian) from the broader perspective of emigration and immigration, thus trying to answer to some of the major questions and related concerns. 
The results show that immigration flows have important economic consequences leading to significant changes in labour market performances both for natives and foreign population (decreases in employment rates and wage levels, higher earnings dispersion), which largely vary from one country to another, so on the short-run, the negative effects of immigration are extremely significant. Still, one of the most important positive effects of immigration reflected by the results obtained is represented by an increase in the number of innovative enterprises in the host country, thus confirming the theories linking migration to innovation.

Thus, migrant host economies need to consider several specific labour market policies in order to cope with large inflows of immigrants and refugees. Active labour market policies (ALMPs) focus on unemployed persons, their implementation providing assistance in finding a job, training for professional development and skills acquirement, wage incentives and direct job creation in the public sector, all of these being extremely necessary for the inclusion of immigrants. The flexicurity policies combine the two perspectives on flexibility and security as main components of European employment strategies. Within this perspective, the overall focus should be on new employment guidelines and job creation for a better coordination of the compatibility between labour demand and supply, together with an improvement in the educational level of the labour force, better working conditions and wage increases for all the EU Member States (both labour exporting and receiving ones).

From the emigration perspective, the findings show positive effects of labour emigration on sending countries, on shortterms, by upgrading the living standards for those remaining (reflected to an increase in earnings level and GDP per capita), mainly through remittances. Still, there is a significant negative impact induced by the loss of a large part of the labour force through emigration (especially highly skilled labour) for the considered economies from Central and Eastern Europe, reflected by the results obtained through decreases in employment rates - both total and temporary employment, as well as on the educational background reflected by a reduction of the participation rate in education and training. Moreover, the results highlight that emigration tends to deepen the poverty levels by increasing the at-risk-of-poverty rates for considered economies.

Overall, the performed analysis confirms some of the main economic consequences of international migration in a global era advanced by the literature regarding the fact that labour mobility, induces both negative and positive effects for migrant sending and receiving economies, which largely vary from one country to another, according to the measures and policies adopted to better cope with this complex phenomenon.

\section{References}

[1] Aubry Amandine, Burzynski Michal, Docquier Frederic (2016), ,The welfare impact of global migration in OECD countries", Journal of International Economics, issue 101, pp. 1-21.

[2] Baum F. Christopher (2001), "An Introduction to Modern Econometrics Using Stata", Stata Press, ISBN 1-59718013-0, pp. 1-341.

[3] Bosetti Valentina, Cattaneo Cristina, Verdolini Elena (2015), „Migration of skilled workers and innovation: A European Perspective", Journal of International Economics, issue 96, pp. 311-322.

[4] Brücker Herbert, Baas Timo, Beleva Iskra, Bertoli Simone, Boeri Tito, Damelang Andreas, Duval Laetitia, Hauptmann Andreas, Fihel Agnieszka, Huber Peter, lara Anna, Ivlevs Artjoms, Jahn Elke, Kaczmarczyk Pawel, Landesmann Michael, Mackiewicz-Lyziak Joanna, Makovec Mattia, Monti Paola, Nowotny Klaus, Okolski Marek, Richter Sandor, Upward Richard, Vidovic Hermine, Wolf Katja, Wolfeil Nina, Wright Peter, Zaiga Krisjane, Zylicz Anna (2009), Labour mobility within the EU in the context of enlargement and the functioning of the transitional arrangements, European Integration Consortium Final Report, Employment, Social Affairs and Equal Opportunities Directorate General of the European Commission (contract VC/2007/0293), Nuremberg 2009.

[5] Clemens Michael (2011), „Economics and Emigration: Trillion-Dollar Bills on the Sidewalk?”, Journal of Economic Perspectives, Vol. 25, No. 3, pp. 83-106.

[6] Dustmann Christian, Frattini Tommaso, Glitz Albrecht (2008), "The Labour Market Impact of Immigration", CReAM Discussion Paper no. 11, Centre for Research and Analysis of Migration, Department of Economics, University College London, pp. 1-27. 
[7] Fassio Claudio, Kalantaryan Sona, Venturini Alessandra (2015), „Human Resources and Innovation: Total Factor Productivity and Foreign Human Capital", Institute for the Study of Labor, Discussion Paper No. 9422, pp. 1-35.

[8] Fertig Michael, Kahanec Martin (2015), "Projections of potential flows to the enlarging EU from Ukraine, Croatia and other Eastern neighbours", IZA Journal of Migration, no. 4, issue 6, pp. 1-27.

[9] Goss Jon, Lindquist Bruce (1995), „Conceptualizing International Labor Migration: A Structuration Perspective”, International Migration Review, Vol. 29, No. 2, pp. 317-351.

[10] Harris R. John, Todaro P. Michael (1970), „Migration, Unemployment and Development: a Two-Sector Analysis”, The American Economic Review, volume 60, issue 1, pp. 126-142.

[11] Hein de Haas (2010), „Migration and Development: A Theoretical Perspective”, International Migration Review, Vol. 44, No. 1, pp. 227-264.

[12] Krause Annabelle, Rinne Ulf, Zimmermann Klaus (2016), "European Labour Market Integration: What the Experts Think", forthcoming International Journal of Manpower 2016, IZA Discussion Paper no. 8383, pp. 1-27.

[13] Kerr William (2014), „U.S. High-Skilled Immigration, Innovation and Entrepreneurship: Empirical Approaches and Evidence", WIPO Economics \& Statistics Series, Economic Research Working Paper No. 16, pp. 1-26.

[14] Kwok Viem, Leland Hayne (1982), „An Economic Model of Brain Drain”, American Economic Review, Vol. 72 , No. 1 (March 1982), pp. 91-100.

[15] Massey S. Douglas, Arango Joaquin, Hugo Graeme, Kouaouci Ali, Pellegrino Adela, Taylor Edward (1993), "Theories of International Migration: A Review and Appraisal", Population and Development Review, vol. 19, issue 3, pp. 431-466.

[16] Noja Gratiela Georgiana, Son Liana, Caran Margareta (2015), "Key Challenges of Emigration from Central and Eastern European Economies: Empirical Evidence", The Macrotheme Review, no. 4, issue 6, pp. 97-110.

[17] Ozgen Ceren (2015), ,Immigration and Firm Innovation in Western-Europe: Understanding the Channels of Influence", Migration Policy Centre, EUI, ISBN 978-92-9084-235-4, pp. 1-12.

[18] OECD (2015), "Is this humanitarian migration crisis different?", Migration Policy Debates, no. 7, September 2015.

[19] OECD (2014), International Migration Outlook, Mobilising Migrants' Skills for Economic Success.

[20] Son Liana, Noja Gratiela Georgiana (2012), „A macroeconometric panel data analysis of the shaping factors of labour emigration within the European Union", Theoretical and Applied Economics, Vol. XIX, No. 11(576), pp. 15-30.

[21] Taylor J. Edward (1986), „Differential Migration, Networks, Information and Risk”, pp. 147-171 in Oded Stark (ed.), Research in Human Capital and Development, Vol. 4, Migration, Human Capital, and Development, Greenwich, JAI Press.

[22] Taylor J. Edward, Arango Joaquin, Hugo Graeme, Kouaouci Ali, Massey S. Douglas, Pellegrino Adela (1996), „International Migration and Community Development”, Population Index, Vol. 62, No. 3, pp. 397-418.

[23] Zimmermann F. Klaus (2005), European Migration: What Do We Know?, Oxford University Press, New York, ISBN 978-0-19-925735-5, pp. 1-653. 